\title{
Evaluation of knowledge and health behavior of University of Medical Sciences students about the prevention of COVID-19
}

\author{
Hamed Zandian ${ }^{\mathrm{a}}$, Mehdi Sarailoo ${ }^{\mathrm{b}}$, Shahriar Dargahic ${ }^{\mathrm{c}}$, Helia Gholizadeh ${ }^{\mathrm{b}}$, \\ Abdollah Dargahi ${ }^{\mathrm{a}, *}$ and Mehdi Vosoughi ${ }^{\mathrm{a}, *}$ \\ ${ }^{a}$ Social Determinants of Health Research Center, Ardabil University of Medical Sciences, Ardabil, Iran \\ ${ }^{\mathrm{b}}$ Students Research Committee, School of Public Health, Ardabil University of Medical Sciences, Ardabil, Iran \\ ${ }^{\mathrm{c}}$ PhD Student of Counseling, University of Mohaghegh Ardabili, Ardabil, Iran
}

Received 20 July 2020

Accepted 30 November 2020

\begin{abstract}
.
BACKGROUND: Coronaviruses are a large family of viruses that have symptoms ranging from the common cold to severe respiratory syndromes.

OBJECTIVE: The purpose of this study is to provide appropriate strategies to raise knowledge and health behavior of students of the University of Medical Sciences to prevent COVID-19.

METHODS: This study was conducted as a cross-sectional and descriptive study, and the online questionnaire was used by random sampling. Our sample size was 360 subjects and the statistical population was the students of the University of Medical Sciences. We used the nonparametric test (Kruskal Wallis, Mann-Whitney U) and (Chi-Square \& $t$-test) for statistical analysis.

RESULTS: The test results were statistically significant for students' health behavior $(p<0.01, \mathrm{df}-99)$. The knowledge of women was higher than men $(F=5.32, p<0.02)$.

CONCLUSION: The results show that the Ministry of Health has acted well in promoting students' knowledge and healthpromoting behaviors. Therefore, it is recommended that such research be conducted in the public statistical population.
\end{abstract}

Keywords: Coronaviruses, health principles, social distance, public attitude

\section{Introduction}

In December 2019, 27 cases of a new type of viral pneumonia from unknown etiology were identified in Wuhan City, Hubei province in China. The World Health Organization (WHO) named the new

*Address for correspondence: Abdollah Dargahi, Department of Environmental and Occupational Health, Social Determinants of Health Research Center, Ardabil University of Medical Sciences, Ardabil, Iran. E-mail: a.dargahi29@yahoo.com. coronavirus as COVID-19 [1, 2]. Coronaviruses are divided into four groups as follows: Alpha coronavirus $(\alpha \mathrm{CoV})$, Beta coronavirus $(\beta \mathrm{CoV})$, Delta coronavirus $(\delta \mathrm{CoV})$, and Gamma coronavirus $(\gamma \mathrm{CoV})$. They are all enveloped, and their genome is positive-sense RNA [3, 4]. Until now, 2019 novel coronavirus (2019-nCoV) infected 44,787,418, and killed $1,179,401$ persons worldwide. In Iran, 588,648 infected and 33,71114 persons died due to COVID-19 [5]. Students of the University of Medical Sciences 
can get the disease due to their presence in health centers and also being at the forefront of the fight against these epidemics. Unfortunately, during their essential roles, they may possibly transmit this disease to other people in the community $[6,7]$. Many studies examined the level of knowledge, awareness, and health behavior $[8,9]$. We cannot say for sure how 2019-nCoV is transmitted, but few studies showed that this virus is transmitted from human to human through respiratory fomites and cough or sneezing [1, $6]$. The transmission of this virus occurs when persons are asymptomatic, and in this case, 2019-nCoV incubation is about 2 up to 10 days [6-8]. Symptoms like fever, shortness of breath, cough, muscle ache are the most common and typical in COVID-19, but in severe cases, septic shock and acute renal injury are so significant $[1,9]$. According to WHO, there is no vaccine and decisive treatment for the 2019 novel coronavirus [10]. As observed in studies, the mean incubation period of COVID-19 is about 5.1 days, and the symptoms in most people appear after 11.5 to 15.6 days [11]. The best approach against the coronavirus is prevention programs such as avoiding close contact with other people, avoiding close contact with farm or wild animals, especially bats [2, 8, 12]. Also, despite many disagreements about the usefulness of wearing a mask in reducing infection and preventing COVID-19, scientific research has focused on the use of masks in crowded places [13]. Health behavior is the activity undertaken by individuals for the purpose of maintaining or enhancing their health, preventing health problems, or achieving a positive body image. According to the introduction, the importance of the study is that by increasing health behavior as well as knowledge about COVID-19, the risk of the virus can be reduced and serious measures can be taken to combat this disease. To achieve effective management in terms of reducing the spread and harm and enhancing the communication protocols, much attention must be paid to health behavior as well as knowledge; thus, the aim of this study was to explore the knowledge and health behavior of the University of Medical Sciences students with a focus on the 2019-nCov.

\section{Materials and methods}

This was a descriptive cross-sectional study to evaluate the level of knowledge and Health Behavior of the University of Medical Sciences students as a target population. We used the online questionnaire and random sampling from 360 students at the
University of Medical Sciences. Because of quarantine and maintaining social distancing, we used an electronic questionnaire to various characteristics of this population to obtain information for checking the knowledge and health behavior.

\subsection{Statistical community and sampling method}

The statistical population of this study includes all students of the University of Medical Sciences. At the University of Medical Sciences, 3630 students are studying in different faculties. Considering $68 \%$ good knowledge (16), 5\% error, $95 \%$ confidence, and Cochran's formula $n=\frac{z_{1-\alpha / 2}^{2} \cdot p(1-p)}{d^{2}}$, at least 360 students were questioned. This number was selected by a stratified random sampling method from the faculties of the University of Medical Sciences. Thus, according to the number of students in each faculty, a certain proportion of them were evaluated by randomness. So that 37 students of the Faculty of Health, 44 people of the School of Paramedical Sciences, 21 students of the School of Dentistry, 76 students of the Faculty of Medicine, 63 students of the Faculty of Nursing and Midwifery, 18 students of the Faculty of Pharmacy, and 62 students of the Faculty of international Campus were selected. The number of samples examined in terms of associate's, bachelor's, master's, professional doctorate, and clinical specialization degree were $13,157,16,160$, and 14 people, respectively.

The questionnaire included two sections; the first section was related to the demographic information, and the second section was containing 10 questions about knowledge and 26 questions about health behavior. We considered 5 items (very low, low, medium, high, and very high) for each question. This 36-item scale has been prepared to measure health knowledge and health behavior against COVID-19, based on the findings of the World Health Organization. The content and validity of the prepared questionnaire were approved by 10 health promotion specialists of the University of Medical Sciences. So that after sending it to these experts, their corrections and specialized opinions were applied both in content and number of questions, and finally this questionnaire was prepared and implemented in 36 items. Out of 36 questionnaire questions presented in this study, 13 questions (questions 1, 2, 3, 4, 8, 14, 15, 16, 17, 21, 22,23 , and 26) were scored in reverse (That is, a low score indicates high knowledge and health behavior) and 23 questions (Questions 6, 7, 9, 10, 11, 12, 13, 18, $19,20,24,25,27,28,29,30,31,32,33,34,35$, and 
Table 1

Electronical questionnaire and participants' knowledge and health behavior

\begin{tabular}{|c|c|c|c|c|c|}
\hline Question & Very low & Low & Medium & High & Very high \\
\hline $\begin{array}{l}\text { Have you used shared fingerprints } \\
\text { in hospitals, banks, etc.? }\end{array}$ & 67 & 12.6 & 11.6 & 4.9 & 3.9 \\
\hline $\begin{array}{l}\text { Have you visited hookah shops } \\
\text { and cafes during this time? }\end{array}$ & 84.5 & 5.8 & 4.8 & 2.9 & 1.9 \\
\hline $\begin{array}{l}\text { How much fast food, restaurant } \\
\text { food, and bulk food have you eaten? }\end{array}$ & 73.8 & 12.6 & 6.8 & 4.8 & 1.9 \\
\hline $\begin{array}{l}\text { How much public health services } \\
\text { have you used during this time? }\end{array}$ & 74.8 & 9.7 & 5.8 & 6.8 & 2.9 \\
\hline $\begin{array}{l}\text { Have you used personal items such as aprons, scissors, } \\
\text { towels, combs and tweezers at the hairdresser? }\end{array}$ & 35 & 8.7 & 9.7 & 16.5 & 30.1 \\
\hline Have you used nylon bags to buy bread? & 23.3 & 11.7 & 18.4 & 25.2 & 21.4 \\
\hline $\begin{array}{l}\text { When you go to the hairdresser's, do you } \\
\text { wash your hands and clean the chairs? }\end{array}$ & 12.6 & 3.9 & 15.5 & 25.2 & 42.7 \\
\hline $\begin{array}{l}\text { Have you used shared work tools such as } \\
\text { computers, staples, pens, desks and chairs? }\end{array}$ & 40.8 & 10.7 & 20.4 & 17.5 & 10.7 \\
\hline $\begin{array}{l}\text { Do you disinfect the red line } \\
\text { at the entrance of the house? }\end{array}$ & 13.6 & 13.6 & 26.2 & 28.2 & 18.4 \\
\hline $\begin{array}{l}\text { Did you change clothes while } \\
\text { entering the house? }\end{array}$ & 4.9 & 10.7 & 17.5 & 35 & 32 \\
\hline Do you use rings, watches and bracelets? & 57.3 & 22.3 & 9.7 & 2.9 & 7.8 \\
\hline $\begin{array}{l}\text { When you enter the house, do you have a specific path for } \\
\text { keeping shoes and socks and not entering the house? }\end{array}$ & 10.7 & 15.5 & 22.3 & 23.3 & 28.2 \\
\hline $\begin{array}{l}\text { Have you disinfected personal items such as } \\
\text { your phone, key, switch and handbag? }\end{array}$ & 1 & 3.9 & 13.6 & 41.7 & 39.8 \\
\hline $\begin{array}{l}\text { Do you think corona is transmitted } \\
\text { from infected bodies? }\end{array}$ & 2.9 & 1 & 10.7 & 27.2 & 58.3 \\
\hline $\begin{array}{l}\text { Have you experienced excessive fear of coronavirus } \\
\text { that could endanger your general health? }\end{array}$ & 41.7 & 19.4 & 18.4 & 13.6 & 6.8 \\
\hline How often do you go to work or study? & 65 & 9.7 & 11.6 & 4.9 & 8.7 \\
\hline How much public transport do you use? & 72.8 & 11.7 & 10.7 & 1.9 & 2.9 \\
\hline $\begin{array}{l}\text { Do you touch your mouth and eyes after } \\
\text { each wash before washing your hands? }\end{array}$ & 66 & 14.6 & 9.7 & 6.8 & 2.9 \\
\hline How many days have you been quarantined at home? & 3.9 & 1.9 & 15.5 & 30.1 & 48.5 \\
\hline Do you use caution in computer game centers? & 2.9 & 4.8 & 3.9 & 7.8 & 80.6 \\
\hline $\begin{array}{l}\text { Have you considered the health principles } \\
\text { of receiving and maintaining money? }\end{array}$ & 1 & 5.8 & 29.1 & 40.8 & 23.3 \\
\hline $\begin{array}{l}\text { Have you traveled during this time } \\
\text { (Corona disease epidemic)? }\end{array}$ & 57.3 & 22.3 & 6.8 & 2.9 & 10.7 \\
\hline $\begin{array}{l}\text { How many visits did you have to the pharmacy during } \\
\text { this period (corona disease epidemic)? }\end{array}$ & 29.1 & 34 & 27.2 & 2.8 & 3.9 \\
\hline $\begin{array}{l}\text { How often did you go to the office to do } \\
\text { personal work during pandemic? }\end{array}$ & 39.5 & 29.2 & 10.1 & 12.8 & 8.4 \\
\hline Did you use virtual education in the spread of the disease? & 9.7 & 15.5 & 24.3 & 26.2 & 24.3 \\
\hline $\begin{array}{l}\text { Based on media and cyberspace training, were you able } \\
\text { to prepare disinfectants from and use them to disinfect surfaces? }\end{array}$ & 16.5 & 17.5 & 28.1 & 19.4 & 18.4 \\
\hline $\begin{array}{l}\text { Have you been in contact with people with Corona or influenza } \\
\text { symptoms during this time? }\end{array}$ & 66 & 14.6 & 10.7 & 5.8 & 2.9 \\
\hline $\begin{array}{l}\text { How many visits did you have to the pharmacy during } \\
\text { this period (corona disease epidemic)? }\end{array}$ & 29.1 & 34 & 27.2 & 5.8 & 3.9 \\
\hline Did you heat the purchased bread properly before use? & 13.5 & 19.4 & 24.3 & 20.4 & 22.3 \\
\hline Have you avoided losing and kissing? & 2.9 & 1 & 10.7 & 27.2 & 58.3 \\
\hline Have you disinfected your money cards after use? & 3.9 & 8.7 & 20.4 & 24.3 & 42.7 \\
\hline $\begin{array}{l}\text { Have you washed or disinfected the equipment } \\
\text { properly after purchase? }\end{array}$ & 0 & 6.8 & 15.5 & 35.9 & 41.7 \\
\hline $\begin{array}{l}\text { Have you observed a distance of } 1 \text { meter from } \\
\text { people in public places? }\end{array}$ & 1 & 5.8 & 29.1 & 40.8 & 23.3 \\
\hline Did you heat the purchased bread properly before use? & 13.5 & 19.4 & 24.3 & 20.4 & 22.3 \\
\hline $\begin{array}{l}\text { Have you observed a distance of } 1 \text { meter } \\
\text { from people in public places? }\end{array}$ & 1 & 5.8 & 29.1 & 40.8 & 23.3 \\
\hline $\begin{array}{l}\text { How many hand sanitizers have you used after contacting } \\
\text { surfaces in public places? }\end{array}$ & 0 & 8.7 & 20.4 & 33 & 37.9 \\
\hline
\end{tabular}


Table 1

(Continued)

\begin{tabular}{|c|c|c|c|c|c|}
\hline Question & Very low & Low & Medium & High & Very high \\
\hline $\begin{array}{l}\text { How much did you wash your hands after going to public } \\
\text { places, according to health authorities? }\end{array}$ & 0 & 0 & 10.7 & 31.1 & 58.3 \\
\hline How much mask and gloves have you used in public? & 3.9 & 5.8 & 27.2 & 34 & 29.1 \\
\hline $\begin{array}{l}\text { In general, how much can you take care of } \\
\text { your health with reasonable fear? }\end{array}$ & 9.1 & 1.3 & 11.5 & 19.7 & 58.4 \\
\hline $\begin{array}{l}\text { Have you tried to keep yourself cheerful without } \\
\text { going to a crowded environment? }\end{array}$ & 23.9 & 19.8 & 8.5 & 19.1 & 28.7 \\
\hline
\end{tabular}

36) were scored directly (i.e., high score indicates high health knowledge and behavior). In addition, in evaluating the reliability of this scale, Cronbach's alpha coefficient for the prepared questionnaire was obtained to be 0.74 , which reveals its good reliability. For statistical analysis, we used the parametric test (descriptive statistics) and (variance analysis, $t$-test), according to the statistical analysis, we used the average rankings instead of the average answers for the dual comparison. Students were divided into 5 grades (Bachelor, MA, Pharmacology, Medical, and Dental). Each person was given a score for the average level of health knowledge and behavior that is considered as a level of general health knowledge and behavior. In this study, for maintaining social distancing, we use an online questionnaire. For designing this questionnaire, we used Google Forms, and to sketch the questions, we used the newest and up to date information based on WHO and valid studies. For getting responses, we sent a link to participants via (WhatsApp, Telegram, and Gmail). After one month, we received 500 responses from our participants. For response extraction, we used Google Forms charts.

\section{Results}

Our questionnaire had 36 questions that participants answer to them. All questions were about health behavior and knowledge on Covid-19. This questionnaire has five items (very low, low, medium, high, and very high), and the knowledge and health behavior were reported in percentages (Table 1). To test the general condition of the sample in terms of knowledge and health behavior compared to the theoretical average, a single $t$-test was used. To do this, first, the score of health knowledge and behavior was divided by the number of questions so that the average on a uniform scale would be standardized. According to the scoring scale of this questionnaire from 1 to 5 , the standardized mean was compared with the average theoretical value, i.e., 2.5. The average age of students
Table 2

Descriptive statistics of students' knowledge and health behavior after uniformity of scale

\begin{tabular}{lccc}
\hline Variables & $\begin{array}{c}\text { Standardized } \\
\text { averages }\end{array}$ & $\begin{array}{c}\text { Standard } \\
\text { deviation }\end{array}$ & $\begin{array}{c}\text { Average } \\
\text { standard } \\
\text { deviation }\end{array}$ \\
\hline $\begin{array}{c}\text { Knowledge } \\
\text { and health } \\
\text { behavior }\end{array}$ & 3.91 & 0.49 & 0.041 \\
\hline
\end{tabular}

Table 3

Descriptive information on the variability of knowledge and health behavior of the participants in the study

\begin{tabular}{lcccc}
\hline & $\begin{array}{c}\text { Average } \\
(\mathrm{M})\end{array}$ & $\begin{array}{c}\text { Standard } \\
\text { deviation } \\
(\mathrm{SD})\end{array}$ & Maximum & Minimum \\
\hline $\begin{array}{c}\text { Knowledge } \\
\text { and health } \\
\text { behavior }\end{array}$ & 140.9 & 14.22 & 169 & 108 \\
\hline
\end{tabular}

was 24.84. 14.6\% had a doctoral degree; $9.7 \%$ had a master's degree; 64.1 had a bachelor's degree, and $11.7 \%$ had a master's degree. $41.7 \%$ were men, and $58.3 \%$ were women. Table 2 shows the descriptive statistics of students' knowledge and health behavior after uniformity of scale. Because of quarantine and maintaining social distancing, we used an electronic questionnaire to various characteristics of this population to obtain information for checking the knowledge and health behavior.

Descriptive information on the variability of knowledge and health behavior of the participants in the study is presented in Table 3. According to Table 3, the highest and lowest levels of awareness and health behavior were 169 and 108, respectively.

The level of the knowledge and health behavioral status of students of University of Medical Sciences in the field of coronavirus disease, according to gender, was classified in Fig. 1. According to Table 4, women who participated in the study had more knowledge and health behavioral than men against coronavirus disease. 


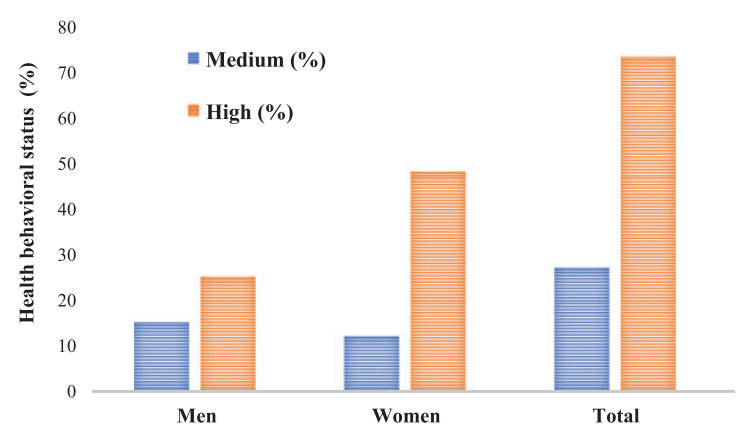

Fig. 1. Information on the knowledge and health behavioral status of students of University of Medical Sciences in the field of coronavirus disease in terms of gender.

As shown in Table 4, the test results were statistically significant for students' health behavior $(P<0.01, \mathrm{df}-359)$. In terms of health behavior, the average students were higher than that of average in society; this means that students have more knowledge about the health behavior of COVID-19 than the society. This shows the favorable situation of the participants in the research in terms of knowledge and health behavior about the disease.

The information in the table shows that the difference between average knowledge and health behavior in men and women is significant. Women are more aware of COVID-19 than men. We did not see a significant difference in knowledge and health behavior average, between marital status and education status factors (Table 5).

\section{Discussion}

During epidemics and pandemics, people in all communities experience a variety of challenges; for example, how to survive and to stay safe from virus, how to use drugs, how to maintain social distance and etc. Lack of knowledge often leads to decreased safe health behaviors, which may adversely affect the preparedness to meet these challenges and problems that threaten our societies. The effect of these epidemics and pandemics events like Covid-19 are often intense and may completely affect the life of the population. Epidemics and pandemics have always brought fear, and this can influence the behavior of people in the community. The aim of this study was the evaluation of knowledge and health behavior about emerging 2019-nCOV, in the University of Medical Science communities. All diseases, such as COVID19 that have the potential to spread have new behavior and unique characteristics, as we saw in Middle East Respiratory Syndrome (MERS) epidemic. It is very important and has a positive effect if we can provide a health education, knowledge, and awareness during such situations, e.g., the COVID-19 pandemic for the effective prevention of disease spread $[14,15]$. Some studies show that the health behavior and knowledge of the community is lower in areas where the prevalence of the disease are lower and fewer people are infected, compared to in high-prevalence areas [16]. The rate of COVID-19 incidence is between medium

Table 4

T-test sample to assess students'knowledge and health behavior

\begin{tabular}{|c|c|c|c|c|c|c|}
\hline \multicolumn{3}{|c|}{ Test value (2.5) } & \multirow{2}{*}{$\begin{array}{l}\text { The degree } \\
\text { of freedom }\end{array}$} & \multirow{2}{*}{$\begin{array}{c}\text { Significance } \\
\text { level }\end{array}$} & \multicolumn{2}{|c|}{$95 \%$ confidence range } \\
\hline Variables & $\begin{array}{c}\text { Average } \\
\text { difference }\end{array}$ & $\mathrm{t}$ & & & Down & Top \\
\hline $\begin{array}{l}\text { Knowledge } \\
\text { and health } \\
\text { behavior }\end{array}$ & 1.41 & 33.44 & 359 & 0.001 & 1.33 & 1.49 \\
\hline
\end{tabular}

Table 5

Descriptive information and analysis of variance to show students' knowledge and health behavior based on gender, marital and educational factors

\begin{tabular}{lcccc}
\hline Variable & Group & Average & $\begin{array}{r}\text { Standard } \\
\text { deviation }\end{array}$ & Significance \\
\hline Gender & Men & 3.75 & 0.44 & $F=5.32 P<0.02$ \\
& Women & 3.99 & 0.40 & \\
Marital status & Single & 3.86 & 0.31 & $F=0.221 P<0.67$ \\
& Married & 3.92 & 0.43 & \\
Education & Ph.D & 4.02 & 6.38 & $F=0.221 P<0.67$ \\
& Masters & 4.17 & 5.07 & \\
& Bachelor & 3.87 & 6.38 & \\
& Associate Degree & 3.87 & 5.07 & \\
\hline
\end{tabular}


and high in the city [17]. Due to the strange behavior of the virus, new information about Corona disease is always needed. The existence of information gaps and the need to increase the knowledge of the participants in this study is fully felt. Therefore, studies must be done, and training must be provided to the participants [18-22]. The average of participants was aged 24.84, and all of them had substantial knowledge and health behavior, but in terms of our result, women had a higher level compared to men. Based on WHO guidelines, maintaining social distancing is very important. Moreover, the scientific studies revealed that everyone is at risk for COVID-19, especially high-risk groups like older adults (people over 65 years of age) patients with serious chronic underlying medical conditions, and the ones that have obesity [23, 24]. Our study showed that $58.3 \%$ of our participants know that COVID-19 can be transmitted from patient persons, and only $23.3 \%$ correctly maintain one-meter distancing in public places. It is suggested that other questionnaires with other physical-psychological and social self-care content be developed and applied to a diverse statistical population. The results show that the Ministry of Health has acted well in promoting students' awareness and health-promoting behaviors. Therefore, the implementation of such research in the public statistical population is recommended. The problem of Internet access as well as the fair and correct distribution of the questionnaire link in all communication channels including WhatsApp, Telegram, and e-mail was the limitation of the researchers in this study.

\section{Conclusion}

The data in this study, which was collected by an electronic questionnaire, could be used as baseline data to monitor public knowledge and to increase health behavior in the event of a future outbreak of infectious and viral diseases, e.g., COVID-19. The presence of medical students at the forefront of the fight against this epidemic and direct exposure to patients with the virus show the value and importance of measuring awareness and attitude in this group. According to COVID-19 pandemic and lack of observing the social distance and daily scientific findings on COVID-19 and its new behaviors, this kind of study and campaigns can improve public attitude and decrease health system costs by preventing COVID-19.

\section{Acknowledgments}

This article is the result of a research project approved by the Social Determinants of Health Research Center, Ardabil University of Medical Sciences (IR.ARUMS.REC.1399.036).

\section{Conflict of interest}

None to report.

\section{References}

[1] Dargahi A, et al. Investigation of SARS CoV-2 virus in environmental surface. Environmental Research. 2021;195:110765.

[2] Sarailoo M, et al. Investigating the relationship between occupation and SARS-CoV2. Work. 2021;68(1):27-32.

[3] Chan JF-W, et al. Genomic characterization of the 2019 novel human-pathogenic coronavirus isolated from a patient with atypical pneumonia after visiting Wuhan. 2020;9(1):221-36.

[4] Chan JF-W, et al. Interspecies transmission and emergence of novel viruses: lessons from bats and birds. 2013;21(10):544-55.

[5] Organization WH, Coronavirus disease (COVID-2019) situation reports. 2020.

[6] Li Q, et al. Early transmission dynamics in Wuhan, China, of novel coronavirus-infected pneumonia. 2020.

[7] Ja BJES, KLinKenBerG d, WaLLinGa J. Incubation period of 2019 novel coronavirus (2019-nCoV) infections among travellers from Wuhan, China, 20-28 January 2020. 2020;25:1-6.

[8] Lauer SA, et al. The incubation period of coronavirus disease 2019 (COVID-19) from publicly reported confirmed cases: estimation and application. 2020;10: M20-0504.

[9] Chen N, et al. Epidemiological and clinical characteristics of 99 cases of 2019 novel coronavirus pneumonia in Wuhan, China: a descriptive study. 2020;395(10223):507-13.

[10] Luo H, et al. Can Chinese medicine be used for prevention of corona virus disease 2019 (COVID-19)? A review of historical classics, research evidence and current prevention programs. 2020:1-8.

[11] Lauer SA, et al. The incubation period of coronavirus disease 2019 (COVID-19) from publicly reported confirmed cases: estimation and application. 2020;172(9):577-82.

[12] Chen X, et al., Hand Hygiene, Mask-Wearing Behaviors and Its Associated Factors during the COVID-19 Epidemic: A Cross-Sectional Study among Primary School Students in Wuhan, China. 2020;17(8):2893.

[13] Feng S, et al. Rational use of face masks in the COVID-19 pandemic. 2020;8(5):434-6.

[14] Wells CR, A.P.J.P.o.l.r. Galvani, Public health impact of disease-behavior dynamics: Comment on "Coupled disease-behavior dynamics on complex networks: A review" by Z. Wang et al. 2015;15:55.

[15] Roy D, et al. Study of knowledge, attitude, anxiety \& perceived mental healthcare need in Indian population 
during COVID-19 pandemic. Asian Journal of Psychiatry. 2020;51:102083.

[16] Kobayashi M, et al. Community knowledge, attitudes, and practices regarding Ebola virus disease-five counties, Liberia, September-October, 2014. 2015;64(26):714.

[17] Arab-Mazar Z, et al. Mapping the incidence of the COVID19 hotspot in Iran - Implications for Travellers. Travel Medicine and Infectious Disease. 2020;34:101630-101630.

[18] Hussain ZA, Hussain SA, Hussain FA. Medical students' knowledge, perceptions, and behavioral intentions towards the H1N1 influenza, swine flu, in Pakistan: A brief report. American Journal of Infection Control. 2012;40(3):e11e13.

[19] Khan MU, et al. Knowledge and attitude of healthcare workers about middle east respiratory syndrome in multispecialty hospitals of Qassim, Saudi Arabia. 2014;14(1):1-7.
[20] Rahnavardi $\mathrm{M}$, et al. Knowledge and attitude toward Crimean-Congo haemorrhagic fever in occupationally atrisk Iranian Healthcare Workers. 2008;69(1):77-85.

[21] Askarian M, Danaei M, Vakili V.J.I.j.o.p.m. Knowledge, attitudes, and practices regarding pandemic $\mathrm{H} 1 \mathrm{~N} 1$ influenza among medical and dental residents and fellowships in Shiraz, Iran. 2013;4(4):396.

[22] Khazaeipour Z, Ranjbarnovin N, Hoseini N.J.T.J.o.I.i.D.C. Influenza immunization rates, knowledge, attitudes and practices of health care workers in Iran. 2010;4(10):636-44.

[23] Lighter J, et al. Obesity in patients younger than 60 years is a risk factor for Covid-19 hospital admission. 2020.

[24] Nicola $M$, et al. Evidence based management guideline for the COVID-19 pandemic - Review article. International Journal of Surgery. 2020;77:206-16. 